\title{
History and the Social Sciences: Shock Therapy with Medieval Economic History as the Patient
}

\author{
Daniel R. Curtis, Bas van Bavel and Tim Soens
}

\begin{abstract}
Since the turn of the Millennium, major changes in economic history practice such as the dominance of econometrics and the championing of "big data," as well as changes in how research is funded, have created new pressures for medieval economic historians to confront. In this article, it is suggested that one way of strengthening the field further is to more explicitly link up with hypotheses posed in other social sciences. The historical record is one "laboratory" in which hypotheses developed by sociologists, economists, and even natural scientists can be explicitly tested, especially using dual forms of geographical and chronological comparison. As one example to demonstrate this, a case is made for the stimulating effect of "disaster studies." Historians have failed to interact with ideas from disaster studies, not only because of the general drift away from the social sciences by the historical discipline, but also because of a twin conception that medieval disaster study bears no relation to the modern, and that medieval coping strategies were hindered by providence, superstition, fear, and panic. We use the medieval disasters context to demonstrate that medieval economic history can contribute to big narratives of our time, including climate change and inequality. This contribution can be in (1) investigating the root causes of vulnerability and resilience, and recovery of societies over the long term (moving disaster studies away from instant impact focus) and (2) providing the social context needed to interpret the massive amount of "big data” produced by historical climatologists, bioarchaeologists, economists, and so on.
\end{abstract}

\section{New Pressures Facing Medieval Economic History}

The so-called cultural or linguistic turn that history took in the late 1980s had a strong impact on the practice of economic and social history. It ultimately pushed social and economic historians to the sidelines of the discipline, although they reacted in different ways. Social history was the first to have an extreme inward reflection on the state of its own field. In the same way that social historians of the Annales School in the 1960s had taken to task "traditional" history based on military and political events and "great men" and "elites," social historians now were challenged by postmodernist lines of thinking questioning previously accepted definitions and processes of categorization commonly employed. History suddenly became an infinite constellation of possible truths. A new type of social history developed, which moved not only away from the social sciences but also from economic history.

The field of economic history had a somewhat lesser amount of inward soul searching: What became clear was that economic historians were increasingly starting to retreat away from the other fields of history and find a "safer haven" in the grounds of 
econometrics. This, together with the preference for more cultural approaches in the historical profession, led to a declining presence of economic history within the top general history journals. In Past and Present, for example, economic history was a key component of the journal's reputation for contentious issues and vigorous debate in the 1970s and 1980s, as seen in clashes over the role of agrarian capitalism (the Brenner Debate) or the "Crisis of the Seventeenth Century." Nowadays, however, economic history takes a much-reduced role within the journal.

This development did not seem to harm economic history, however, because its turn toward econometrics initially proved successful. Although the cliometric approach to economic history had taken root in the 1960s (on its early achievements; McCloskey 1978), its popularity soared from 1990s onward, made feasible by the ability to compile large amounts of data and perform quicker calculations through wider access to computers. So despite the reduced presence of economic history in top history journals such as Past and Present throughout the past 20 years, economic history journals have actually established a strong position for themselves. The top five economic history journals are mostly ranked in the top five positions for the "History of Social Sciences" category, whatever form of measurement one wishes to take, while in the broader category of "History," the Economic History Review is second to only the American Historical Review in terms of five-year impact factor and "Article Influence Score." In addition, very recent literature has posited that economic history is gaining ground in respectability and visibility within economics, at least in the United States, shown by a growing share of historical studies in leading economics journals (Abramitzky 2015). That is not to say there has not been some inward reflection from economic historians about the state of the field today. The journal Historically Speaking devoted passionate contributions discussing "The Neglected Field of Economic History?" in 2010, and in 2015 the Journal of Economic History offered a forum for differing views on "The Future of Economic History," while the appearance of the book The Poverty of Clio by Francesco Boldizzoni in 2011, directly challenging the apparent hold of cliometrics over the profession, provoked extreme reactions in both praise and (oft-entertaining) rebuttal (McCloskey 2013).

The case of medieval economic history, however, is more complicated. On the one hand, there are some indicators of stagnation or even decline. The medieval period has taken a much-smaller proportion of the overall output for the top economic history journals such as Journal of Economic History and Economic History Review, while specifically medieval journals such as Speculum and Journal of Medieval History rarely offer anything on an economically oriented topic nowadays. While participation from medievalists seems to be strong at the annual Economic History Society Conference in the United Kingdom, at the largest meeting of economic historians from across the world, the tri-annual World Economic History Congress, very few

1. Taken from the ISI Web of Knowledge Journal Citation Reports 2014. The "top five economic history journals" relate to the Journal of Economic History, Economic History Review, European Review of Economic History, Explorations in Economic History, and Cliometrica. Various forms of journal measurement are used including impact factor, five-year impact factor, Eigenfactor Score, and Article Influence Score. For the category history, many economic history journals such as Journal of Economic History did not rank themselves here-further illustrating the gap between economic history and the other historical disciplines. 
sessions can now be found with an explicitly medieval topic-evidenced especially by the recent congress in Kyoto in 2015. And yet, on the other hand, neither developments are necessarily compelling evidence for a decline in fortunes in medieval economic history, but simply a result of the "globalization" of the discipline and a rise in new research interests into areas such as inequality in Latin America or the roots of underdevelopment in Africa. Put simply, it is not necessarily that less medieval economic history is being published but instead more of everything else. In fact, on some levels, medieval economic history has strengthened its position since the turn of the Millennium, especially in a body of research that now makes a case for modern economic development having some roots in the medieval period (van Bavel 2010). Indeed, while early literature on the "Great Divergence," a debate essentially on the causes and timing of the global disparity between select parts of "the West" and "the rest," suggested that the economic divide between Northwest Europe and China may only have taken place relatively late, around the eighteenth and early nineteenth centuries (Pomeranz 2000), other scholars have seriously suggested that the roots of the divergence may already have its institutional origins from the Middle Ages (Kuran 2010; van Zanden 2009; on the "Little Divergence" across Europe; Malanima 2009; Pamuk 2007).

That is not to say there are not challenges and difficulties that medieval economic history also faces. Indeed, one of the negative knock-on impacts of economic history now placing more precedence on (1) econometrics and (2) the compilation of large quantitative digital data sets is simply that these kinds of methods are not always as suitable for research into the medieval period. Data is not only much scarcer, but is often not as readily quantifiable, and this is particularly problematic when one considers that econometric calculations are reliant on having high-quality series with very few gaps or missing figures. Elsewhere, the recent Organisation for Economic Co-operation and Development (OECD) report How Was Life? moves away from the reliance on traditional economic indicators of well-being to offer massive global data sets on living standards across the globe between 1820 and 2000 (van Zanden et al. 2014), and yet, how many of these same indicators can be reconstructed going back much further in time-all the way to the Middle Ages? Very few, in all likelihood, and ultimately this leads to the privileging of the recent centuries over the distant past. The recent History Manifesto, as a call to arms to historians interested in promoting the role of history for contemporary society, is very positive about the association between new forms of digitalized "big data" and our ability to eschew short-term approaches to the past in favor, once again, of the longue durée-essentially laudable sentiments (Guldi and Armitage 2014). And yet we have a paradox that these "big data" approaches are not altogether employable for periods as far back as the Middle Ages_-and when they are, only for limited parts of the world. Big data and the long term do not go as seamlessly hand in hand as Guldi and Armitage suggest.

Additionally, continuing moves toward the "macro" and, more specifically, the desire to offer reconstructions of, for example, gross domestic product (GDP) across large parts of the globe going back in time, not only works generally to the disadvantage of the study of the medieval period, but furthermore privileges certain parts of the world such as England, with the good fortune to have manorial accounts at 
its disposal, to the detriment of all those places in Europe and the rest of the world (the majority) that do not (Broadberry et al. 2015). And finally, a further difficulty of more recent nature for medieval economic historians is the fact that funding bodies are now increasingly asking scholars to be very explicit in the "social relevance" of their research: direct deliverables, valorization, and knowledge utilization. As one can imagine, these kinds of things are not always a hallmark of medieval historical research, even if the medieval period is now starting to be inserted into important debates on the global disparities in wealth and poverty.

Rather than taking a defensive stance against the increasing need to offer "social relevance" as "justification" for our research, however, medieval economic historians should be openly flaunting their qualities that could actually help contribute to furthering scientific debates with relevance for the present-a sentiment shared in the History Manifesto. In the remainder of this article, it is suggested that one way of doing this is for medieval economic historians to empirically test hypotheses derived from other disciplines of the social sciences, and help build convincing long-term narratives. We substantiate this point by elaborating upon the example of a field that medieval economic history may be further invigorated by, namely, disaster studies. This blossoming field has in recent years posed a number of interesting hypotheses as to why some societies cope more effectively in the face of exogenous shocks and hazards, some of which are being tested on contemporary societies, and yet these ideas have barely filtered through to the traditional historical disciplines.

The remainder of the article is then divided up into the following sections: In section two the field of disaster studies is briefly introduced, with a discussion of why these ideas have not filtered through to historians. In section three, it is shown why the Middle Ages are a good "laboratory" for further research into societal and economic responses from severe environmental shocks and hazards. Particular emphasis is first put on the potential to perform new kinds of comparative experiments and assess economic and societal change and continuities not just in the immediate aftermath of shocks but also over very long chronologies. Second, it is demonstrated that whatever new figures might be uncovered over the long term in this era of "big data" and digitalization, for example from the burgeoning fields of historical climatology or bioarchaeology, this data will only make sense and have value by assessment within specific historical contexts—contextual conditions that medieval historians in particular have a very good understanding of.

\section{Disaster Studies and Its Lack of Translation to History}

Academic and popular interest into hazards and shocks, and the disasters that can ensue, has never been stronger. Books focusing on the collapse of whole societies and civilizations under environmental strain have achieved international best-seller status (Diamond 2005), and this is perhaps unsurprising given such dangers have not dissipated with time-if anything, the transition to "modernity" and "cosmopolitanism" has made our lives inherently more "risky" if Ulrich Beck is to be believed (1992). 
In academia, this broader interest has been translated into a thriving field of "disaster studies"- emerging from its early roots as a facet of the natural sciences into a discipline more in line with the social sciences. In fact, under the early guidance of one of the discipline's true pioneers, Henry Quarantelli, "disaster studies" scholars have now iterated that environmental hazards cannot be seen as merely "natural occurrences" (1987; also Dynes 1975; and more recently Cardona 2004; Steinberg 2000), but as social, cultural, and political processes testing the capacity of societies to organize themselves, limit initial destabilization, and move onto a stage of recovery (Blaikie et al. 2004 [1994]; Pelling 2012 [2003]; Tierney 2007). In effect, some societies, just in the way they are set up, ordered, or arranged, can be more capable of dealing with shocks and hazards than others. Material aspects such as technology, wealth, and infrastructure are still often invoked as explanatory factors in the differential capabilities of societies to deal with shocks and hazards - often combined with the optimistic notion that market forces would always ensure that technological innovation meets climate change problems or ecological challenges (Shafik 1994). However, recent failures of even the wealthiest and most technologically advanced countries in the world have instructed us that technical knowledge and economic resources do not inevitably lead to more effective short-term responses or long-term recoveries (Hartman and Squires 2006), but equally important are the institutional and cultural frameworks channeling their use (Ostrom 1990; Sen 1988).

A shift away from the "natural environment," the catastrophic "event," and technocratic ideology, together with a heightened focus on the intrinsic qualities of societies, should be good news for historians. However, despite a disparate body of historical literature dealing with disasters in the past, very little of this work has, as of yet, explicitly linked up with hypotheses put forward in the contemporary "disaster studies" discipline. While a broad range of social science fields have actively attempted to try and define and measure different elements of "risk," "resilience," and "vulnerability," and offered up hypotheses to test relating to the coping capacity of different societies, such ideas have hardly filtered through to historians (noted in Curtis and van Bavel 2016; Lübken and Mauch 2011: 4; Schenk 2007a). Well-established journals such as Disasters and the International Journal of Mass Emergencies and Disasters have a paucity of articles devoted to disasters before the twentieth century, while in a recent overview from an important "disaster studies" handbook, fields as diverse as sociology, law, anthropology, environmental sciences, demography, geography, economics, development studies, media studies, psychology, and public administration are mentioned, but history is entirely absent (McEntire 2007).

Such lack of integration may partially be down to some level of resistance on the disaster studies side, but more than likely, it is the opposite that is to blame. The discipline of history has up to now not been able to sufficiently contribute and integrate itself with the main ideas discussed by scholars of contemporary disasters because of the regrettable move away from the social sciences by the traditional historical profession (van Bavel 2015). One thing the historian fears more than anything is to be accused of being "deterministic," and despite being dismissed back in the 1960s and 1970s with the rise of new forms of social history, "events" and the "narrative" have 
made a partial revival. Back in the 1960s and 1970s, historians were using historical perspectives as actual material for public reform-scholars such as Eric Hobsbawm argued for the liberating use of history as a set of past precedents for contemporary change (1972, 1997). Nowadays it seems more than ever that historians are convinced that the past in itself cannot be used to establish regularities, patterns, and certainly not laws, and to identify and test these through comparative analysis.

As a result, the shifting position of history away from the social sciences has meant the "past" has failed to be used as an adequate "laboratory" for testing ideas and hypotheses with social relevance for the present-surely one of the most important functions of history (Diamond and Robinson 2012). As argued in the recent History Manifesto, long-term history should ideally be a tool for understanding modern institutions, rendering utopian schemes comprehensible, and rendering revolutionary programs for social change thinkable (Guldi and Armitage 2014: 24). Medieval economic historians (and economic historians in general) might be able to forge a bridge between the social sciences and the humanities. This can be initiated through the "arena" of a more coherent agenda and approach to the study of historical disasters, as just one example.

This is not to say that it is easy for historians to connect to current disaster research. A more specific block, particularly for the Middle Ages, has been the notion established in disaster research that the Anthropocene, an age of human-induced climatic, biological, and geophysical change, is far different to the "disaster context" seen in the preindustrial period. In the eyes of many disaster scholars, the roots of the Anthropocene cannot be traced further back than the Industrial Revolution and the transition from solar energy to fossil fuels, and even then, the global environment only changing profoundly after great acceleration in the post-World War II period (Oldfield et al. 2014; Steffen et al. 2007). Furthermore, the work of Ulrich Beck, already mentioned, by establishing "risk" as a logical by-product of technological and intellectual modernity, with the artificial separation of nature and culture only attributable to the Scientific Revolution of the seventeenth and eighteenth centuries, has in the process made us question the actual relevance of studying premodern disasters at all (Revet 2011). This view has been further entrenched by a past tradition of cultural historical research into disasters focusing on "popular mentality" and "perception" that has cultivated an image of the medieval period, in particular, as a time of superstitious hysteria and hopelessness, with fear, the "unknown," and faith being considerable barriers to hazard mitigation, risk management, and long-term recovery.

We argue that there are many reasons to remove these blocks. First of all, recent investigations on the interaction between humans and nature suggest that the eighteenth-century political, social, and economic "revolutions" are less of a fundamental transition than earlier assumed. Current discussions on the start of the Anthropocene vary between 1610 (when the depopulation of the Americas in the wake of European Conquest produced the first anthropogenic global dip in atmospheric carbon dioxide) and 1964 (when nuclear bomb testing left a global impact in 14C levels) (Lewis and Maslin 2015). Some scholars have even suggested the use of the term Palaeoanthropocene for the entire period between the Neolithic and the 
Industrial Revolution (Foley et al. 2013). Ultimately, the emphasis on indicators of global change obscures the fact that the Anthropocene is a colossal "black box," composed of different processes like urbanization, deforestation, globalization, fossil fuels, or artificial fertilizers. Each of these components has its own history, unfolding in very different ways in various parts of the Earth, and affecting different people in a variety of ways (Biermann et al. 2015). Most of these histories do not start in the eighteenth century, but way back in the medieval period or even before. In a more systematic way, Jason Moore (2014) has argued for the rise of "world ecology" linked to capitalist modes of production, originating in the "long" sixteenth century. Such capitalist world ecology essentially combined short-termist strategies of resource extraction; a metabolic rift between nutrient production and consumption; and a radical simplification of nature, as witnessed by monocultures. Already in the second half of the fifteenth century, interconnected examples of this new ecology could be found from peat mining industries of Holland to the Madeira sugar plantations, while significant deforestation and inland sand drifts can be traced even earlier in the Middle Ages such as in the Veluwe of the Central Netherlands, caused largely by the development of iron production in the tenth century (van Bavel 2010: 23, 48).

Second, we argue that the focus on religiosity and panic in relation to medieval disasters is misguided, or at least one-sided. The point here is not to dismiss the significance of the "religious" response to hazards and shocks in the medieval period: Indeed, it is clear that many responses centered around the power of prayer and devotion, charity and piety, the veneration of saints, and the use of relics. And this was understandable given such calamities were considered to be acts of divine retribution, possibly for moral degeneration. Environmental hazards and epidemics alike were apparently "designed to edify and teach humility, patience, and faith" (Porter 1993: 1451). The notion that most medieval societies, both in the Latin West and the Middle East, saw these environmental hazards as punishments from God, tends to fit more easily with a narrative emphasizing their "inevitably" disruptive impact and panicked response. In the early stages of the 1315 famine across parts of Northern Europe, religious figures marched barefoot in the fields in recompense for the failed harvest (Jordan 1996). Later in the fifteenth century, mass processions in the context of recurrent disease continued to occur, bearing communal relics through the streets, with sermons encouraging congregations to "avoid sin"- an official application of collective penitence (Murphy 2013: 150). In numerous cases after severe environmental shocks or epidemics, religious orders urged for greater sanctions to reinforce social norms such as the ending of overindulgent celebrations and immodest behavior (Cohn 2002; Schenk 2007b).

These manifestations of piety, lack of scientific knowledge, fear, and hysteria have greatly influenced the literature on historical disasters. The greater proportion of literature over the past years has established a narrative based around an "inevitable" disaster-fear-disorder nexus. According to the classic works of Jean Delumeau, for example, hazards and shocks unsettled medieval societies, breaking them from "normal" patterns and were instrumentalized by the Church to create fear and angst (1978). Such a view was particularly entrenched within the study of epidemic diseases that 
apparently throughout history had "always" led to excessive social responses based on hatred, fear, and blame of easily targetable groups (from the early Baehrel 1951, 1952; to the more modern Nirenberg 2015 [1996]: 231-50). And likewise, plentiful evidence has been assembled in the literature to show elements of "societal breakdown" in the Middle Ages, stemming from interaction with severe shocks and hazards. After the Black Death, violent pogroms were initiated in some places, where Jewish families were gathered up and burnt to death (Cohn 2007a), while others have pointed to plague's capacity to echo and amplify existing social tensions, increasing thefts, violence (Chiffoleau 1980), and a general rise in "confusion, fraud and lawlessness" (Shirk 1981: 357), while reducing public safety (Bowsky 1964). Similarly, with harvest failures, substantial evidence has been collected for their incendiary impact on criminality and violence (Hanawalt 1974; Stevens 2015: 34-35).

However, by privileging elements of hysteria and hopelessness, superstition and faith, this obscures the fact that medieval societies offered quite different responses to the same shocks. Ultimately, the existence of religion, superstition, or even "fear" did not preclude coping strategies in other ways (Gerrard and Petley 2013). Even if the occurrence of an actual shock or hazard was perhaps "out of their hands" and some sort of divine intervention, medieval populations still attempted to mitigate the initial effects of an unexpected shock using a variety of institutions and, furthermore, even used knowledge and institutions to reduce the risk of material or human losses in the future (Richardson 2005). Alongside God's intervention in human or natural affairs, these events also stimulated communal solidarity and neighborliness, or alternatively afforded opportunity to investigate responsibility of actors involved, including neighbors or authorities (Morgan 2015: 48). Institutional and providential responses were not mutually exclusive. So for example, even more than the divine punishment in the form of plague, people had similar fear for the public health restrictions that inevitably ensued, lessening citizens' freedoms, curtailing their ritual engagements, and impinging upon customary community ties and collective practices-and often expressed in active or passive resistance to the prevailing discourse (Coudert 2008: 733).

Indeed, it is becoming increasingly clear that hazards and shocks did not "inevitably" break down the bonds of human compassion nor diminish the capacity for medieval societies to negotiate and work together. In times of harvest failure, urban governments might lower taxes on importations of foodstuffs, or negotiate with rural communities into providing the necessary labor reservoir to oversee and conduct repairs in times of flood (Curtis and Campopiano 2014). Even the "deep-seated" fear and angst of the destructive power of the sea was sometimes turned around and used as a point of cohesion, as flood protection mobilized the mutual aid and assistance of all members of the community (Soens 2009; van Tielhof 2015). In some contexts, the Black Death was an opportunity for governments to impose strong and coercive labor and migration regulations imposed from above, and yet in other places, when faced with similar severity of shock, more moderate, even compassionate, pieces of legislation were drawn up (Cohn 2007b). Literature on historical pandemics, particularly in recent years, has begun to take issue with the inevitable association of plague and 
societal decay, with more explicit regard for regional and chronological divergences (Cohn 2012, 2015; Dean 2015). As Paul Slack once said, "[S] udden disastrous events such as epidemics illuminate many facets of the societies with which they collide. They create situations of stress which test the institutions, and the habits of mind and behaviour, which normally hold society together" (Slack 1985: 4).

We can even go a step further. The preceding focused on institutions specifically designed to cope with a hazard, either in preparation or anticipation of future danger or when confronted with a hazard. Most institutions that determined societal coping capacity, however, were not specifically developed with an eye on hazard response but for very different purposes. The organization of commodity markets, for example, allowing efficient and rapid mobilization of goods or capital, in turn alleviating the effects of a shock or natural hazard, was designed for economic, social, or political reasons not explicitly connected to hazards. Likewise, social networks and reciprocal relations may have been instrumental in coping with disasters, but were mostly not developed with explicitly this in mind.

It is also important to note that the set of relevant institutions was completely different per region, in the medieval period more so than in the modern era. Among them were also institutional and technological arrangements that in the modern era have been marginalized, under the growing influence of both markets and states. One can think of cooperative and collective arrangements, as found in the communal administration of land use in mountain, forest, or heathland regions or craft guilds in cities. Such "subaltern" medieval institutional and technological arrangements present important empirical cases for any researcher interested in testing the strengths and weaknesses of new solutions to important societal challenges today. For example, in the wake of global climate change and sea-level rise, there is growing consensus among marine scientists that the traditional answer of modernity to the problem of coastal flood protection, being large, centralized, and capital- and energy-intensive technological systems, cannot guarantee the "absolute" level of protection demanded by coastal populations at risk (Tessler et al. 2015). New strategies of coastal management often turn to the creation of more room for excess flood water, for instance through coastal realignment, controlled flooding, the creation of "buffer capacity" (Temmerman and Kirwan 2015). Some of these "new" strategies are surprisingly close to those developed by medieval coastal societies (Rippon 2000). Some medieval communities in the North Sea coastal area concentrated their settlements on artificial elevations raised upon the sea level. ${ }^{2}$ Early embankments compartmented the landscape, creating several lines of defense. Communal surveillance, maintenance, and alerting systems provided large segments of coastal societies with a thorough acquaintance of flood hazards and how to act in times of danger. Such technological and institutional arrangements were not inherently superior or inferior to modern ones: They worked smoothly in some contexts and failed elsewhere. Such a wide array of technologies, institutional arrangements, and social and economic contexts, and their histories of failure and success, make medieval coastal flood protection 
arrangements excellent cases to investigate present-day issues of flood protection and environmental change. And the emphasis here should be on "test": Decay and disorder were not "inevitable" but dependent on interaction between hazard, institutions, and culture.

So the point being made then is this: Rather than overprivileging responses to hazards and shocks from the medieval Church, with a focus on fear, angst, and superstition, it is clear that different medieval societies had quite different responses and coping strategies when met with the same type of shock or hazard, even when these very same societies shared the conception that the causes were divine punishment. A point of further research is to understand why some medieval societies also failed to establish or enact these solutions, or rather their solutions took very different forms and manners (Curtis 2014). On the one side we can look to differential characteristics of the shocks. For example, it has been recently said that repeat occurrences of severe shocks over time, rather than one-off unheard of catastrophes, tended to reinforce a more sophisticated array of coping mechanisms and organization based on applied knowledge (Mauelshagen 2009: 44). Cultural memory has now been regarded as a fundamental component of coping and learning from previous hazards (Bankoff 2003; Pfister 2009). And it is true that most premodern societies experienced hazards and shocks as part of their frequent and recurring "life experience" (Bankoff 2013), even if this state of "preparedness" was never constant and changed over time (Soens 2011).

And on the other side we can look at the conditions that (1) allow certain institutional responses to emerge in the first place, and (2) allow certain institutional responses to be more effective than others. The extent to which a medieval producer could look to the market to save them during hardship was dependent on the precise terms by which they could conduct trade: Taxes and extra-economic burdens proved to be powerful dissuaders, for example (Brenner 1976). Similarly, the extent to which medieval societies relied on resources from the commons often depended on the extent to which rights and privileges were bestowed differentially down the social hierarchy (Curtis 2015; De Keyzer 2013), while the extent to which rural producers relied on systems of credit, insurance, or support to ease their way through floods, periods of conflict, or harvest failures was also dependent on the precise nature of reciprocal networks between groups and individuals at a very microlevel. In the Great Famine of 1315-17, for example, it recently has been argued that the "generalized trust" characteristic of trade between strangers in "normal" years was broken, and accordingly, buyers and sellers switched to alternative reliable "particularized trust," limited to small groups of communities based on personal networks of reputation (Slavin 2014). In some cases, wealthy creditors may have taken advantage of less prosperous neighbors during periods of sudden hardship, but in other cases, creditordebtor relations were more reciprocal and less unidirectional (Briggs 2009: 151-55, 190-93; Schofield 2008). Rather than accepting an overarching narrative based on fear or inevitable panicked responses or descent into disorder, but instead one receptive to regionally divergent responses with varying levels of extremity and effectiveness, we can establish a more analytical brand of medieval economic history. As seen in the 
next section, however, this can only come from more systematic use of spatial and chronological comparative research.

\section{Medieval Economic History and Disaster Research: Its Contribution}

So far it has been argued that one way in which medieval economic history could be enhanced further is to act as a bridge between the humanities and the social sciences, which have in recent years drifted further apart. This could be achieved by empirically testing hypotheses and ideas developed from new social science fields such as disaster studies. In the following section, two specific ways are discussed where medieval economic historians can make a real contribution to furthering our knowledge about how different societies dealt and deal with hazards and shocks in both the immediate aftermath and the long term.

\section{The Possibilities for Spatial and Chronological Comparison}

Comparative analysis, spatially and chronologically, is the main tool we can employ for description and explanation. Medievalists in particular, trained in case selection, empirical research, and critical assessment and interpretation of data in context, know how to use such analytical tools to their maximum potential. Accordingly, medieval economic historians can also bring some of the benefits of the comparative method to the study of historical disasters - benefits that are specifically (or mainly) attributable to the "special" laboratory of the Middle Ages.

Indeed, one element that medieval economic historians can benefit from is their capacity to offer up all kinds of different comparisons, made easier by the flexibility with which we move between dependent, independent, and control variables. This is helped by the fact that several of the most devastating mortality crises, in the process completely shifting the balance between people and resources in a short space of time, occurred in the Middle Ages. Perhaps the most conspicuous one was the Black Death, reducing overall European population levels by at least 30 percent and in some places more. The Black Death not only naturally offers up its own potential for comparative research, but also facilitates the creation of other comparative experiments focusing on other shocks and hazards that would be difficult to perform in other periods. By drastically changing the demographic situation of most European regions in a rapid movement, this offers a rupture point through which population pressure can be invoked as a significant control and independent variable, when testing the coping capacity of different medieval societies. Thus, first of all, comparative research can be performed when holding population pressure on resources constant. Comparing the response of a number of different societies to the Great Famine of 1315-17 makes sense when all societies are experiencing extremely high pressure on resources. Similarly comparing the response of different societies in the late fourteenth and early fifteenth centuries also makes sense because it is very likely that population 
pressure can be held constant as a variable_-although the Black Death did not exactly strike every region with the precise same intensity and chronology, in general its large demographic impact was widespread enough to mean that if one is comparing flooding or famine between a number of different societies in early-fifteenth-century Europe, it will likely be between societies all experiencing a relatively low intensity of resource use.

Alternatively, the devastating shock of the Great Famine of 1315-17 allows the Middle Ages to be an excellent laboratory for testing the effects of population pressure on resources as an independent variable in societies' capacity to cope with hazards and shocks. Indeed, it has often been suggested that famines such as that of 131517 were so severe as a result of the strong pressure on finite amounts of resources that many European societies were experiencing at the time (Bailey 1998; Schofield 1997). Land morcellation and incessant fragmentation into tiny plots exacerbated the consequences of the Great Famine (Campbell 2009). And yet, this kind of hypothesis, though intuitively logical, has barely been subject to formal testing. Those focusing on the Great Famine have tended to only approach the subject in isolation (Jordan 1996; Kershaw 1973), likely on account of fascination with its overall extremity. What the dramatic changes in overall population levels following the Black Death allow medieval economic historians to do is compare dearth, harvest failure, and famine responses of the same society, but now with different population densities. Famine in Europe did not begin or end with 1315-17, but continued intermittently through the Middle Ages into the early modern period and beyond (for a chronology; Alfani and Ó Gráda 2017). So how did societies react to harvest failures in times of resource scarcity, and how did they react to harvest failure in times of resource plenty? Are there any differences in the mechanisms and institutions involved? Of course the comparison of both pre- and post-Black Death periods with an explicit test on the impact of population pressure needs not only be restricted to episodes of harvest failure but can also apply to other shocks such as floods and seismic activity.

Furthermore, one of the flaws in the current disaster studies literature is that it almost entirely concentrates on short-term impacts. This is understandable when most disaster studies scholars tend to focus on contemporary shocks and hazards, or at least those of the twentieth century-the historical record is simply not there to carry out time series analysis over long periods. So, for example, in a recent review on the impact of fluctuations in temperature, precipitation, and storminess, few studies are mentioned concentrating on the medium- or long-term impact of hazards and shocks beyond five or 10 years, and indeed, this is explicitly marked out as a major gap in the existing economic and institutional literature on disasters (Dell et al. 2014: 778-80). One of the real advantages that medieval economic historians then have is the relative abundance of cases and long-term historical perspective. Historians can stand back and give an important long-term perspective to changes in our economy and society that have been forged through sharp rupture points caused by hazards and shocks (Bankoff 2004). As medieval economic historians know, it takes the view of centuries, not decades, to observe more clearly fundamental economic change in its true guise. 
And as medieval economic historians, we can help shift the emphasis of much contemporary disaster studies literature away from reliance on abstract macrovalues such as GDP, when considering the "effectiveness" or "quality" of economic response to severe hazards and shocks. At best, the decline and subsequent recovery of GDP might indicate the "resilience" of economic systems, but they do not inform us on disruption of individual livelihoods. Thanks to, for instance, international aid or largescale public investment programs, or institutional changes, the economy of a region or state can boom in the aftermath of a disaster, as was the case in Lisbon after the 1755 Earthquake (Pereira 2009). However, these economic boosts may also hide profound social disruption, as local populations were displaced and existing land rights overruled by state officials, real estate developers, and new settlers profiting from the "window of opportunity" presented by the disaster. To measure changes in the fate of individual livelihoods affected by shocks, other indicators are needed. And partly because there are no real sources for GDP in our era (or rather its measurement is always subject to a lack of exactitude; even work on medieval England is based on proxies from manorial accounts; Broadberry et al. 2015), we are able to assert a number of other valuable indicators for long-term economic recovery of societies after terrible shocks and hazards - perhaps not the amount and diversity of indicators suggested in the recent OECD report or the Human Development Indexes established by Amartya Sen, but significant ones nonetheless.

Indeed, it is clear that terrible environmental shocks and hazards do not just provide devastating amounts of damage to capital goods, the ruination of agricultural lands, or the death of human beings, and furthermore, do not merely stimulate or retard economies and societies on an aggregate level. Environmental shocks and hazards also have strong powers of redistribution, and medieval economic historians are in a good position to provide a long-term perspective as to whether short-term shocks can make societies more equal or unequal, and whether this is a structural change and made persistent over time.

Inequality plays a role in shaping the context in which societies cope with hazards, but is affected by resulting disasters. Here, large opportunities exist for medieval economic history to analyze this dual interaction between hazards and inequality in the very long run. However, despite renewed interest in distribution issues, our understanding of the long-term development of economic inequality-going back into the preindustrial period - is still very limited. This is down, first of all, to the lack of empirical research attempting to reconstruct distribution of resources (wealth, real estate, or land) or income prior to the Industrial Revolution. Most literature still tends to focus on inequalities forged from the eighteenth century onward (Piketty 2014): The recently developed "inequality possibility frontier" was based on just eight data observations from between the fourteenth and eighteenth centuries (Milanovic et al. 2011). Only very recently has there been a spate of works based on archival evidence to reconstruct long-term trends in inequality (Alfani 2010a, 2010b; Fourie and Von Fintel 2010; Hanus 2013; Hoffman et al. 2002; Pereira et al. 2013), yet there is almost nothing from the medieval period. Furthermore, those much older works able to reconstruct property or wealth distribution further back in time for the Middle 
Ages have generally only done this for short time periods or single dates-often reliant on exceptional or "special" sources such as the 1427 Florentine Catasto or the 1279-80 Hundred Rolls (Bekar and Reed 2013; Herlihy and Klapisch-Zuber 1978). However, in very recent years, a few select pioneering works have appeared that show that reconstruction of different types of inequality for the (late) Middle Ages can be possible, can be integrated with longer-run series of inequality connecting to the early modern period, and do not necessarily need to be restricted to places with better source provision such as England or Italy (Alfani 2015; Alfani and Ammannati 2014), but have been attempted for parts of the Low Countries (Ryckbosch 2016; van Bavel 2009), Portugal (Johnson 2001), and for the Kingdom of Valencia (Baydal Sala and Martí 2014), for example.

But second of all, the main overarching theoretical frameworks for why preindustrial societies became more unequal have in recent times proven to be less convincing. The idea based on the Kuznets Curve that preindustrial economic inequality was inextricably linked to economic growth, and that this association between growth and inequality would only end with the incipient stages of modern industrialization at more advanced stages of economic maturity (van Zanden 1995), has now been challenged. Indeed, recent literature has also shown that preindustrial inequality in the distribution of wealth and land also took place in conditions of economic stagnation and even decline (Alfani 2010a; Pereira et al. 2013), and concentration of wealth and resources was not always a necessary precondition of industrialization (Saito 2014). What is being suggested now is that the roots of modern-day inequality may have very diverse causes, which diverged over time and space (Curtis 2013) and was not at all a linear development.

This is perhaps revealing of the fact that sudden short-term shocks (such as environmental hazards and calamities) could have a substantial redistributive impact for resources, property, and wealth, and furthermore, sometimes this could have lasting effects. Thus, for example, a number of medieval economic historians (in the same way as development economists of contemporary societies) have drawn a connection between overly burdened peasants, distress or panic land sales, and harvest failures and famines (Campbell 2009; Davies and Kissock 2004; Jordan 1996: 91; Kershaw 1973: 37-41). Periods of dearth apparently helped to consolidate the position of large landlords who could manipulate markets to the detriment of poor peasants or agricultural laborers (Galloway 1988: 277). Less clear, however, is the extent to which such pressures had persistent and long-lasting effects on the distribution of property within societies: Were peasants able to regain either their original property or other sources of income once negotiating the initial hardships, or did this set into motion the first stages of land consolidation and large farm creation? Medieval floods have also been invoked as a way of bringing about strong changes in property relationsstimulating peasant property abandonment through the lack of capital buffers, or expropriation from the pressures of consolidating wealthy urban or elite investors in places as diverse as Ming China, Mamluk Egypt, and late medieval Flanders (Borsch 2004; Perdue 1982; Soens 2011), and yet such consequences were never inevitable as recent literature has shown (Curtis 2016; van Cruyningen 2014: 250). 
Focus too can be given to the redistributive impact of epidemic shocks such as plague in the medieval period. More than 40 years ago now, David Herlihy once made the claim that the Black Death caused a greater equality in the distribution of resources in the short term-testament to the prevailing partible inheritance practices and splintering of property between sons (1967). And yet over the medium and long term this gave way to greater inequality-testament to new conditions created in the land and housing market characterized by speculation and consolidation (Curtis 2012; Herlihy 1968). In recent times, however, this interpretation has been turned on its head-showing how the Black Death in many parts of Northern and Central Italy led to the establishment of great equality in distribution of wealth and property over a number of centuries - only dissipating much later in the sixteenth century (Alfani 2015; Alfani and Ammannati 2014). Ultimately, the point is this-neither famine, flooding, nor the Black Death inevitably produced one particular redistributive trend - the direction of redistribution was actually quite diverse and dependent on the specific social and institutional context in which the shock occurred. While plague led to land consolidation in some parts of Europe or the establishment of new social hierarchies within some communities, it led to the widespread access to land for previously disadvantaged social groups in other parts. Medieval economic historians are in a good position to contribute to debates on the long-term redistributive impact of hazards and shocks, in particular, because they are able to systematically take apart and compare a wide range of specific historical social contexts into which the redistributive effect of shocks and hazards are filtered.

\section{The Possibilities to Contextualize "Big Data"}

"Big data" approaches to historical research have taken off in recent years, a trend that has found overwhelming support in the History Manifesto as a potential platform for returning to "big questions" and "longue durée" approaches to the past (Guldi and Armitage 2014). The digital age has enhanced our capacity in economic history to produce bigger data sets than ever before, with national and international research money being increasingly made available to develop large-scale data infrastructure to produce more and more quantifiable figures and numbers for different indicators in historical societies. However, as noted in a recent retort to the History Manifesto, there has been far too much uncritical acceptance and trumpeting of the big data phenomenon, without careful understanding of its costs and benefits, opportunities, and limitations (Cohen and Mandler 2015: 541). With explicit regard to historical disasters, much of the new quantifiable data now being uncovered is being produced in multidisciplinary teams, often not by historians but by economists, paleo-climatologists, biologists, or bio-archaeologists. Some of this data is extremely valuable, but what is argued in the following section is that medieval historians still have an important role in adding further value (and caution) to the figures by first reconsidering the sources being used to compile such data, and then by assessing these numbers within very specific historical social contexts. 
One aspect of disaster studies research that medieval economic historians can profitably contribute to is the historical climate. Alongside the development of inequality, climate change was earmarked in the History Manifesto as a main area in which historians can help build convincing long-term narratives. Indeed, historians are increasingly being included as part of international multidisciplinary teams of paleo-climatologists, processing and interpreting early instrumental climate data in so-called data rescue initiatives (Brunet and Jones 2011). This is importantly taking place for the period 1000-1750 CE, a period lacking instrumental data, but with a wide array of "documentary" proxies (direct or indirect observations of weather conditions in diaries, accounts, chronicles, and ship logbooks). Most interest lies in compilation of massive data sets such as those produced and published on "Euroclimhist" or "tambora.org." Any historian collaborating on such a project will be aware that the overall quality and accuracy of data in the eleventh and the seventeenth century is of a completely different order, and a huge amount of source criticism and contextualization is needed (as consistently argued by field pioneers like Christian Pfister or Pierre Alexandre). Nevertheless, such remarks get lost when documentary data are subsequently statistically processed into long-term reconstructions of temperature and precipitation over the past centuries (Glaser and Rieman 2009 for Germany and Central Europe or Shabalova and Van Engelen 2003 for the Low Countries). Medieval historians are in a good position with their training in source criticism to bring out the flaws in this process. By narrowing down the chronological and geographic frame of analysis, and carefully selecting sources to be processed, more reliable indices of temperature and precipitation can be produced (Camenisch 2015 for the fifteenthcentury Low Countries, Litzenburger 2015 for Metz in the same period, or Pribyl et al. 2012 for East Anglia in the thirteenth to fifteenth centuries), which can subsequently be correlated to other proxy data produced by dendrochronology or glaciology, for instance.

The call for historical "proxies" is most urgent in fields where limited other data are available, for instance when reconstructing storm activity in the past (Buisman 1995-2006; de Kraker 2013; Lamb and Fryendahl 1991). Yet the problem with these reconstructions is that they are not based on actual data for storm surges per se, but what was "perceived to have been" a storm by contemporary commentators, often in chronicles, mostly because of the impact they had on human societies. And so despite entry in climate data forums such as tambora.org, we still do not know whether levels of historical storminess over time were actually variations in storms per se, or instead variations in capacity for societies to deal with storms. The flaws in this data can be further highlighted by turning to criticism of the medieval sources: Many of the so-called storms and resultant "flood disasters" referred to by chroniclers, particularly in the medieval period, turned out to be overexaggerations, suffered from severe imprecision in timing and geography, or were even complete myths (Knottnerus 2013). In fact, reliance on these kinds of sources has led to an overestimation of the frequency and intensity of medieval floods in comparison to the sixteenth and seventeenth centuries, when browsing through regional gazetteers (Bailey 1991; Gottschalk 1971-77). Hence, what medieval historians can do for "big data" data 
sets produced in the field of historical climatology is provide assurances and caution about the types and use of documentary sources-especially in light of increasing popularity of digital databases such as tambora.org.

An even bigger challenge for historians involved in paleo-climatology is to push contextualization one step further and to investigate the complex link between climate, environment, and society. Similar drops in temperature can have completely different meanings, impact, and consequences between different historical societies. Although recent books such as Geoffrey Parker's on the seventeenth-century "crisis" have perpetuated a view, based on cherry picking of supportive cases, that phenomena such as the Little Ice Age created disruption on a global scale (2013), regardless of where and how one lived, it is clear that climatic instability and environmental hazards that ensued were not the same everywhere. Careful comparison of data on prices and mortalities would show us that even in regions very close together, harvest failures such as that of the early 1690s did not produce equivalent effects (Ó Gráda and Chevet 2002). Once again only by narrowing the chronological and geographical framework to well-controlled regional contexts, can this help us investigate whether global climate change was indeed forcing political and economic crisis all over the world, or just producing a "global coincidence" as Paul Warde (2015) provocatively labeled it. The consolidation of all this new data on the climate, in many cases going back into the Middle Ages, is a positive development—but the challenge for medieval historians now is to take some of these state-of-the-art data sets on, for example, historical grape harvests or tree-ring evidence, and assess what they meant for specific historical societies. Bruce Campbell may be correct in suggesting that economic historians should pay more attention to the environment as a "historical protagonist"; fourteenth-century climatic shifts and environmental and biological shocks pushed human history on a new course (2010). But were divergences between the development of societies affected by differential severity, magnitude, or types of shock, or was it instead the case that environment was indeed a "historical protagonist," but its effects and impact differentially refracted and filtered by interaction with already prevailing differential institutions and cultures (Slavin 2014: 11; see also on this subject Slavin 2016)?

\section{Conclusion}

Despite substantial progress in the field of medieval economy history, where the medieval period is now featuring more prominently in some of the big debates in economic history, medieval economic historians also have had to deal with two main changes in the way mainstream economic history is conducted nowadays - a greater reliance and prevalence of econometrics and the move toward the "big data" phenomenon in the digital age - as well as broader changes to the way social sciences and humanities research is funded. So as well as progress, medieval economic history has also had to overcome some new challenges. The main argument of the article is that to further strengthen the discipline, in light of these new conditions and changes, 
medieval historians should look to empirically test hypotheses and assertions made in other social sciences in a more systematic way.

One potential forum through which medieval economic history could stimulate itself is a closer interaction with the new burgeoning discipline of disaster studies. Although disaster studies ideas have filtered through to a number of social science disciplines, however, very little has reached historians. First of all, we suggest that this is due to the shift of history away from social sciences in recent years, but also second, on emphasizing the distinctiveness of the Anthropocene and how the modern age has little in common with the medieval. We suggest that this has been exacerbated by overprivileging the religious responses to terrible shocks and hazards, without recognition that medieval people did not merely accept imposed religious "disaster discourses," religious or spiritual responses to hazards and shocks did not preclude other coping mechanisms, and furthermore, the nature and effectiveness of these responses and institutions were quite diverse. Making it a goal to understand this diversity makes for a more analytical form of medieval economic history. Accordingly, we suggest that the specific contribution that medieval economic historians could make is twofold. First of all, by offering up new possibilities for spatial and longitudinal comparisons, either through the flexible maneuvering of dependent, independent, and control variables or through offering a much-needed long-term perspective (on important developments such as the roots of inequality). Second of all, by acting as a place to contextualize large data sets, often produced by those outside the historical discipline in the era of big data. Medieval economic historians can use their own training to provide muchneeded source criticism and contextual background to forge new narratives based on the pool of historical climatological data now being uncovered.

Finally, we end on two clarifications. First of all, it must be made clear that we use the case of disaster studies as an appropriate example, but similar arguments could be easily made for other social science disciplines: The Middle Ages remains an excellent laboratory for empirically testing game-theoretical approaches to decisionmaking processes or the effective management of common goods, for example. Even natural science and laboratory-based disciplines can be employed. One need not look any further than the pioneering approach taken by Samuel Cohn: using his skills, knowledge, and training as a medieval historian to review and even challenge new data and hypotheses offered by biologists and bio-archaeologists on the origins or causes of epidemic diseases (2002). Second of all, we realize also that the emphasis on getting medieval economic historians to focus on "big questions," make more systematic comparisons, and connect research over longer time periods to more recent developments may be problematic in the sense that the large-scale international grants to support this kind of research have very intense levels of competition. But as a response to this, we suggest that by urging medieval economic historians to start incorporating more systematically some of the ideas and methods taken from the other social sciences, and to more explicitly use the "past" as an adequate "laboratory" for testing hypotheses with social relevance for the present, we will drive up the chances of medieval economic historians actually securing these grants, when under competition from other disciplines, and thus further building and strengthening the field. 


\section{Acknowledgments}

We thank Conor Kostick for inviting us to present this at the Making the Medieval Relevant Workshop funded by the British Academy at the University of Nottingham. We also benefitted from audiences at the Old and New Worlds: The Global Challenges of Rural History Conference in Lisbon, the Regards Croisés sur les Études Médiévales Workshop at the Sorbonne University in Paris, and the Medieval Economic History Seminar at the University of Cambridge led by Chris Briggs. Research for this article was funded by an ERC Advanced Grant for the Coordinating for Life project at Utrecht University (grant no. 339647) and a NWO VENI Grant for the Why Do Some Epidemics Lead to Hatred? project at Leiden University (grant no. 275-53-014).

\section{References}

Abramitzky, R. (2015) "Economics and the modern economic historian." Journal of Economic History 75 (4): $1240-51$.

Alfani, G. (2010a) "Wealth inequalities and population dynamics in Northern Italy during the early modern period." Journal of Interdisciplinary History 40 (4): 513-49.

(2010b) "The effects of plague on the distribution of property: Ivrea, Northern Italy, 1630." Population Studies 64 (1): 61-75.

- (2015) "Economic inequality in Northwestern Italy: A long-term view (fourteenth to eighteenth centuries)." Journal of Economic History 75 (4): 1058-96.

Alfani, G., and F. Ammannati (2014) "Economic inequality and poverty in the very long run: the case of the Florentine State," https://ideas.repec.org/p/don/donwpa/070.html (accessed January 15, 2016).

Alfani, G., and C. Ó Gráda, eds. (2017) Famines in Premodern Europe, Eleventh-Nineteenth Centuries. Cambridge: Cambridge University Press: forthcoming.

Baehrel, R. (1951) "Epidémie et terreur: histoire et sociologie." Annales Historiques de la Révolution Française 23 (211): 113-46.

_ (1952) "La haine de classe en temps d'épidémie." Annales: ESC 7 (3): 351-60.

Bailey, M. (1991) "Per Impetum Maris: Natural disaster and economic decline in Eastern England, 12751350," in B. Campbell (ed.) Before the Black Death: Essays in the Crisis of the Early Fourteenth Century. Manchester, UK: Manchester University Press: 191-99.

(1998): "Peasant welfare in England, 1290-1348." Economic History Review 51 (2): 223-51.

Bankoff, G. (2003) Cultures of Disaster: Society and Natural Hazards in the Philippines. London: Routledge.

(2004) "Time is of the essence: Disasters, vulnerability and history." International Journal of Mass Emergencies and Disasters 22 (3): 23-42.

- (2013) "The 'English Lowlands' and the North Sea Basin system: A history of shared risk." Environment and History 19 (1): 3-37.

(2010) Manors and Markets: Economy and Society in the Low Countries, 500-1600. Oxford: Oxford University Press.

(2015) "History as a laboratory to better understand the formation of institutions." Journal of Institutional Economics 11 (1): 69-91.

Baydal Sala, V., and F. Esquilache Martí (2014) "Exploitation and differentiation: Economic and social stratification in the rural Muslim communities of the Kingdom of Valencia, 13th-16th centuries," in F. Aparisi and V. Royo (eds.) Beyond Lords and Peasants: Rural Elites and Economic Differentiation in Pre-Modern Europe. Valencia: Universitat de València Press: 37-68.

Beck, U. (1992) Risk Society: Towards a New Modernity. London: Sage Publications. 
Bekar, C., and C. Reed (2013) "Land markets and inequality: Evidence from medieval England." European Review of Economic History 17 (3): 294-317.

Biermann, F., et al. (2015) "Down to earth: Contextualizing the Anthropocene." Global Environmental Change 39: 341-50.

Blaikie, P., T. Cannon, I. Davis, and B. Wisner (2004 [1994]) At Risk: Natural Hazards, People's Vulnerability, and Disasters, 2nd ed. London: Routledge.

Boldizzoni, F. (2011) The Poverty of Clio: Resurrecting Economic History. Princeton, NJ: Princeton University Press.

Borsch, S. (2004) "Environment and population: The collapse of large irrigation systems reconsidered." Comparative Studies in Society and History 46 (3): 451-68.

Bowsky, W. (1964) "The impact of the Black Death upon Sienese government and society." Speculum 39 (1): $1-34$

Brenner, R. (1976) “Agrarian class structure and economic development in pre-industrial Europe.” Past and Present 70: 30-75.

Briggs, C. (2009) Credit and Village Society in Fourteenth-Century England. Oxford: Oxford University Press.

Broadberry, S., B. Campbell, A. Klein, M. Overton, and B. van Leeuwen (2015) British Economic Growth, 1270-1870. Cambridge: Cambridge University Press.

Brunet, M., and P. Jones (2011) "Data rescue initiatives: Bringing historical climate data into the 21st century." Climate Research 47 (1-2): 29-40.

Buisman, J. (1995-2006) Duizend jaar weer, wind en water in de Lage Landen. Franeker: Van Wijnen.

Camenisch, C. (2015) "Endless cold: A seasonal reconstruction of temperature and precipitation in the Burgundian Low Countries during the 15 th century based on documentary evidence." Climate of the Past 11: 1049-66.

Campbell, B. (2009). "Factor markets in England before the Black Death." Continuity and Change 24 (1): 79-106.

(2010) "Nature as historical protagonist: Environment and society in pre-industrial England." Economic History Review 63 (2): 281-314.

Cardona, O. (2004) "The need for rethinking the concepts of vulnerability and risk from a holistic perspective: A necessary review and criticism for effective risk management," in G. Bankoff, G. Frerks and D. Hilhorst (eds.) Mapping Vulnerability: Disasters, Development and People. London: Routledge: 37-51.

Chiffoleau, J. (1980) "La violence au quotidien Avignon au XIVe siècle d'après les registres de la cour temporelle.” Mélanges d'École Française de Rome: Modernes 92 (2): 325-71.

Cohen, D., and P. Mandler (2015) “The History Manifesto: A critique." American Historical Review 120 (2): 530-42.

Cohn, S. (2002). The Black Death Transformed: Disease and Culture in Early Renaissance Europe. London: Arnold.

- (2007a) "The Black Death and the burning of Jews." Past and Present 196: 3-36.

(2007b) "After the Black Death: Labour legislation and attitudes towards labour in late-medieval Western Europe.” Economic History Review 60 (3): 457-85.

- (2012) "Pandemics: Waves of disease, waves of hate from the Plague of Athens to A.I.D.S." Historical Research 85 (230): 535-55.

(2015) "Coping with epidemic crises, from Antiquity to the present," in A. Brown, A. Burn, and R. Doherty (eds.) Crises in Economic and Social History: A Comparative Perspective. Woodbridge: The Boydell Press: 189-212.

Coudert, A. (2008) "Sewers, cesspools and privies: Waste as reality and metaphor in pre-modern cities," in A. Classen (ed.) Urban Space in the Middle Ages and the Early Modern Age. New York: Walter de Gruyter: 713-33.

Curtis, D. (2012) "Florence and its hinterlands in the late Middle Ages: Contrasting fortunes in the Tuscan countryside, 1300-1500." Journal of Medieval History 38 (4): 472-99. 
(2013) "Is there an 'agro-town' model for Southern Italy? Exploring the diverse roots and development of the agro-town structure through a comparative case study in Apulia." Continuity and Change 28 (3): 377-419.

(2014) Coping with Crisis: The Resilience and Vulnerability of Pre-Industrial Settlements. Farnham, UK: Ashgate.

(2015) "Did the commons make medieval and early modern rural societies more equitable? A survey of evidence from across Western Europe, 1300-1800.” Journal of Agrarian Change EV: 1-19.

(2016) "Danger and displacement in the Dollard: The 1509 flooding of the Dollard Sea (Groningen) and its impact on long-term inequality in the distribution of property." Environment and History 22 (1): 103-35.

Curtis, D., and M. Campopiano (2014) "Medieval land reclamation and the creation of new societies: Comparing Holland and the Po Valley, c. 800-c. 1500." Journal of Historical Geography 44: 93-108.

Curtis, D., and B. van Bavel (2016) "Better understanding disasters by better using history: Systematically using the historical record as one way to advance research into disasters." International Journal of Mass Emergencies and Disasters 34 (1): 143-69.

Davies, M., and J. Kissock (2004) "The feet of fines, the land market and the English agricultural crisis of 1315 to 1322 ." Journal of Historical Geography 30: 215-30.

Dean, T. (2015) "Plague and crime in Bologna, 1348-1351." Continuity and Change 30 (3): 367-93.

De Keyzer, M. (2013) "The impact of different distributions of power on access rights to the common wastelands: The Campine, Brecklands, and Geest compared.” Journal of Institutional Economics 9 (4): 517-42.

de Kraker, A. (2013) "Storminess in the Low Countries, 1350-1725." Environment and History 19 (2): 149-72.

Dell, M., B. Jones, and B. Olken (2014) "What do we learn from the weather? The new climate-economy literature.” Journal of Economic Literature 52: 740-98.

Delumeau, J. (1978) La peur en Occident: une cité assiégée (XIVe-XVII siècle). Paris: Fayard.

Diamond, J. (2005) Collapse: How Societies Choose to Fail or Succeed. New York: Penguin.

Diamond, J., and J. Robinson, eds. (2012) Natural Experiments of History. Cambridge, MA: Harvard University Press.

Dynes, R. (1975) “The comparative study of disaster: A social organizational approach.” Mass Emergencies 1 (1): 21-31.

Foley, S. et al. (2013) "The Palaeoanthropocene-the beginnings of anthropogenic environmental change." Anthropocene 3: 83-88.

Fourie, J., and D. von Fintel (2010) "The dynamics of inequality in a newly settled, pre-industrial society: The case of the Cape Colony." Cliometrica 4 (3): 229-67.

Galloway, P. (1988) "Basic patterns in annual variations in fertility, nuptiality, mortality, and prices in pre-industrial Europe.” Population Studies 42 (2): 275-303.

Gerrard, C., and D. Petley (2013) "A risk society? Environmental hazards, risk and resilience in the later Middle Ages in Europe.” Natural Hazards 69 (1): 1051-79.

Glaser, R., and D. Riemann (2009) "A thousand-year record of temperature variations for Germany and Central Europe based on documentary data.” Journal of Quaternary Science 24: 437-49.

Gottschalk, M. (1971-7) Stormvloeden en rivier-overstromingen in Nederland, 500-1700. 3 vols. Assen: Van Gorcum.

Guldi, J., and D. Armitage (2014) The History Manifesto. Cambridge: Cambridge University Press.

Hanawalt, B. (1974) "Economic influences on the pattern of crime in England, 1300-1348." American Journal of Legal History 18 (4): 281-97.

Hanus, J. (2013) "Real inequality in the early modern Low Countries: The city of "s-Hertogenbosch, 1500-1660." Economic History Review 66 (3): 733-56.

Hartman, C., and G. Squires (2006) There Is No Such Thing as a Natural Disaster: Race, Class, and Hurricane Katrina. Abingdon: Taylor and Francis.

Herlihy, D. (1967) Medieval and Renaissance Pistoia. New Haven: Yale University Press. 
(1968) "Santa Maria Impruneta: A rural commune in the late Middle Ages," in N. Rubinstein (ed.) Florentine Studies. London: Faber and Faber: 242-76.

Herlihy, D., and C. Klapisch-Zuber (1978) Les Toscans et leurs familles. Une étude du Catasto florentin de 1427. Paris: Editions de l'Ecole des Hautes Etudes en Sciences Sociales.

Hobsbawm, E. (1972) "The social function of the past: Some questions." Past and Present 55: 3-17. (1997) On History. New York: The New York Press.

Hoffman, P., D. Jacks, P. Levin, and P. Lindert (2002) "Real inequality in Europe since 1500." Journal of Economic History 62 (2): 322-55.

Johnson, H. (2001) "Malthus confirmed? Being some reflections on the changing distribution of wealth and income in Portugal (1309-1789)," http://people.virginia.edu/ hbj8n/malthus.pdf (accessed August 30, 2015).

Jordan, W.C. (1996) The Great Famine: Northern Europe in the Early Fourteenth Century. Princeton, NJ: Princeton University Press.

Kershaw, I. (1973) “The Great Famine and agrarian crisis in England, 1315-1322.” Past and Present 59: 3-50.

Knottnerus, O. (2013) "Dollardgeschiedenis(sen)—mythe en realiteit," in K. Essink (ed.) Stormvloed 1509_-geschiedenis van de Dollard. Groningen: Stichting Verdronken Geschiedenis: 95-116.

Kuran, T. (2010) The Long Divergence: How Islamic Law Held Back the Middle East. Princeton, NJ: Princeton University Press.

Lamb, H., and K. Fryendahl (1991) Historic Storms of the North Sea, British Isles, and Northwest Europe. Cambridge: Cambridge University Press.

Lewis, S., and M. Maslin (2015) "Defining the Anthropocene.” Nature 519 (7542): 171-80.

Litzenburger, L. (2015) Une ville face au climat. Metz à la fin du Moyen Âge (1400-1530). Nancy: Éditions Universitaires de Lorraine.

Lübken, U., and C. Mauch (2011) "Uncertain environments: Natural hazards, risk and insurance in historical perspective." Environment and History 17 (1): 1-12.

Malanima, P. (2009) Pre-Modern European Economy: One Thousand Years (10th-19th Centuries). Leiden, The Netherlands: Brill.

Mauelshagen, F. (2009) "Disaster and political culture in Germany since 1500," in C. Mauch and C. Pfister (eds.) Natural Disasters, Cultural Responses: Case Studies towards a Global Environmental History. Lanham, MD: Lexington Books: 41-76.

McCloskey, Deirdre (2013) "The poverty of Boldizzoni: Resurrecting the German Historical School." Investigaciones de Historia Económica 9 (1): 2-6.

McCloskey, Donald (1978) "The achievements of the Cliometric School.” Journal of Economic History 38 (1): 13-28.

McEntire, D. ed. (2007) Disciplines, Disasters and Divergence of Concepts, Issues and Trends from the Research Literature. Springfield: Charles C. Thomas.

Milanovic, B., P. Lindert, and J. Williamson (2011) "Pre-industrial inequality." The Economic Journal 121 (551): 255-72.

Moore, J. (2014) "The Capitalocene, Part I: On the nature and origins of our ecological crisis." http:// www.jasonwmoore.com/Essays.html (accessed January 20, 2016).

Morgan, J. (2015) "Understanding flooding in Early Modern England.” Journal of Historical Geography 50: 37-50.

Murphy, N. (2013) "Plague ordinances and the management of infectious diseases in northern French towns, c. 1450-c. 1560," in L. Clark and C. Rawcliffe (eds.) The Fifteenth Century, Vol. XII: Society in an Age of Plague. Woodbridge: The Boydell Press: 139-61.

Nirenberg, D. (2015 [1996]) Communities of Violence: Persecution of Minorities in the Middle Ages. Princeton: Princeton University Press.

Ó Gráda, C., and J. M. Chevet (2002) "Famine and market in Ancien Régime France.” Journal of Economic History 62 (3): 706-33.

Oldfield, F. et al. (2014) "The Anthropocene Review: Its significance, implications and the rationale for a new transdisciplinary journal." The Anthropocene Review 1 (1): 3-7. 
Ostrom, E. (1990) Governing the Commons: The Evolution of Institutions for Collective Action. Cambridge: Cambridge University Press.

Pamuk, S. (2007) "The Black Death and the origins of the 'Great Divergence' across Europe, 1300-1600." European Review of Economic History 11 (3): 289-317.

Parker, G. (2013) Global Crisis: War, Climate Change and Catastrophe in the Seventeenth Century. New Haven, CT: Yale University Press.

Pelling, M. (2012 [2003]) The Vulnerability of Cities: Natural Disasters and Social Resilience. New York: Earthscan.

Perdue, P. (1982) "Official goals and local interests: Water control in the Dongting Lake region during the Ming and Qing periods.” Journal of Asian Studies 41 (4): 747-65.

Pereira, A. (2009) "The opportunity of a disaster: The economic impact of the 1755 Lisbon Earthquake." Journal of Economic History 69 (2): 466-99.

Pereira, A., J. Reis, and A. M. Silva (2013) "How unequal is Latin inequality? Five centuries of wage inequality, Portugal 1500-2000," http://eh.net/eha/wp-content/uploads/2013/11/Pereira_0.pdf (accessed December 15, 2015).

Pfister, C. (2009) "Learning from nature-induced disasters: Considerations from historical case Studies in Western Europe," in C. Mauch and C. Pfister (eds.) Natural Disasters, Cultural Responses: Case Studies towards a Global Environmental History. Lanham, MD: Lexington Books: 17-40.

Piketty, T. (2014) Capital in the Twenty-First Century. New York: Harvard University Press.

Pomeranz, K. (2000) China, Europe, and the Making of the Modern World Economy. Princeton, NJ: Princeton University Press.

Porter, R. (1993) "Religion and medicine," in W. Bynum and R. Porter (eds.) Companion Encyclopedia of the History of Medicine. London: Routledge: 1449-68.

Pribyl, K., R. Cornes, and C. Pfister (2012) "Reconstructing medieval April-July mean temperatures in East Anglia, 1256-1431." Climatic Change 113 (2): 393-412.

Quarantelli, H. (1987) "Disaster Studies: An analysis of the social historical factors affecting the development of research in the area." International Journal of Mass Emergencies and Disasters 5 (3): 285-310.

Revet, S. (2011) "Penser et affronter les désastres: un panorama des recherches en sciences sociales et des politiques internationales." Critique Internationale 52 (3): 157-73.

Richardson, G. (2005) "The prudent village: Risk pooling institutions in medieval English agriculture." Journal of Economic History 65 (2): 386-413.

Rippon, S. (2000) The Transformation of Coastal Wetlands: Exploitation and Management of Marshland Landscapes. London: The British Academy.

Ryckbosch, W. (2016) "Economic inequality and growth before the Industrial Revolution: The case of the Low Countries (fourteenth to nineteenth centuries)." European Review of Economic History 20 (1): $1-22$.

Saito, O. (2014) "Growth and inequality in the Great and Little Divergence debate: A Japanese perspective." Economic History Review 68 (2): 399-419.

Schenk, G. J. (2007a) "Historical disaster research: State of research, concepts, methods and case studies." Historical Social Research 32 (3): 9-35.

_ (2007b) “ “. . . prima ci fu la cagione de la mala provedenza de' Fiorentini . . ' Disaster and 'life world'-reactions in the commune of Florence to the flood of November 1333." The Medieval History Journal 10 (1-2): 355-86.

Schofield, P. (1997) "Dearth, debt and the local land market in a thirteenth-century village community." Agricultural History Review 45 (1): 1-17.

(2008) "The social economy of the medieval village in the early fourteenth century." Economic History Review 61 (S1): 38-63.

Sen, A. (1988) Poverty and Famine: An Essay on Entitlement and Deprivation. Oxford: Clarendon Press.

Shabalova, M., and A. van Engelen (2003) "Evaluation of a reconstruction of winter and summer temperatures in the Low Countries, AD 764-1998." Climatic Change 58 (1): 219-42.

Shafik, N. (1994) "Economic development and environmental quality: An econometric analysis." Oxford Economic Papers 46: 757-73. 
Shirk, M. (1981) “The Black Death in Aragon, 1348-1351.” Journal of Medieval History 7 (4): 357-68. Slack, P. (1985) The Impact of Plague in Tudor and Stuart England. London: Routledge.

Slavin, P. (2014) "Market failure during the Great Famine in England and Wales (1315-1317)." Past and Present 222: 9-49.

(2016) "Climate and famines: A historical reassessment." Climate Change 7 (3): 433-47.

Soens, T. (2009) De spade in de dijk? Waterbeheer en rurale samenleving in de Vlaamse kustvlakte (12801580). Ghent: Academia Press.

(2011) "Floods and money: Funding drainage and flood control in coastal Flanders from the thirteenth to the sixteenth centuries." Continuity and Change 26 (3): 333-65.

Steffen, W., P. Crutzen, and J. McNeill (2007) "The Anthropocene: Are humans now overwhelming the great forces of nature?" Royal Swedish Academy of Sciences: Ambio 36 (8): 614-21.

Steinberg, T. (2000) Acts of God: The Unnatural History of Natural Disaster in America. Oxford: Oxford University Press.

Stevens, M. (2015) “The Great Famine in Dyffryn Clwyd, 1315-22." Denbighshire Historical Society Transactions 63: 13-36.

Temmerman, S., and M. Kirwan (2015) "Building land with a rising sea." Science 349 (6248): 588-89.

Tessler, Z. (2015) "Profiling risk and sustainability in coastal deltas of the world." Science 349 (6248): 638-43.

Tierney, K. (2007) "From the margins to the mainstream? Disaster research at the crossroads." Annual Review of Sociology 33: 503-25.

van Bavel, B. (2009) "Rural development and landownership in Holland, c. 1400-1650," in O. Gelderblom (ed.) The Political Economy of the Dutch Republic. Farnham, UK: Ashgate: 167-96.

van Cruyningen, P. (2014) "From disaster to sustainability: Floods, changing property relations and water management in the south-western Netherlands, c. 1500-1800." Continuity and Change 29 (2): 241-65.

van Tielhof, M. (2015) "Forced solidarity: Maintenance of coastal defences along the North Sea coast in the early modern period." Environment and History 21 (3): 319-50.

van Zanden, J. L. (1995) "Tracing the beginning of the Kuznets Curve: Western Europe during the early modern period." Economic History Review 48 (4): 643-64.

(2009) The Long Road to the Industrial Revolution: The European Economy in a Global Perspective, 1000-1800. Leiden, The Netherlands: Brill.

van Zanden, J. L. et al., eds. (2014) How Was Life? Global Well-Being since 1820. Amsterdam: OECD Publishing.

Warde, P. (2015) “Global crisis or global coincidence?” Past and Present 228: 287-301. 